\title{
JUMLAH RELATIF SEL NEUTROFIL (GR-1+) PADA MENCIT (MUS MUSCULUS) TERINFEKSI STAPHYLOCOCCUS AUREUS SETELAH PEMBERIAN EKSTRAK BUAH MENGKUDU (MORINDA CITRIFOLIA L.)
}

\author{
Zumrotul Mufidah \\ Staf Pengajar Biomedik, Fakultas Kedokteran,Universitas Nahdlatul Ulama Surabaya \\ Email: zumrotulmufidah@unusa.ac.id
}

\begin{abstract}
Objective: The aim of this study was to determine the relative number of neutrophil (GR-1+) on mice infected Staphylococcus aureus after treatment noni (Morinda citrifolia L.) crude extract. Methods: Mice were devided into two group: non-infected and infected. Non infected group was without S.aureus infection whereas the infected group was infected with S.aureus. Group contain kontrol, dose 1 ( $25 \mathrm{mg} / \mathrm{kg} \mathrm{BW})$, dose 2 $(100 \mathrm{mg} / \mathrm{kg} \mathrm{BW})$, and dose $3(300 \mathrm{mg} / \mathrm{kg} \mathrm{BW})$. Oral treatment carried out for 20 days in every morning and each sample was injected with S.aureus at day 21 with 109 cell $/ \mathrm{mL}$. Relative number of neutrophil (GR-1+) was measured using the BD FACSCaliburTM Flowcytometer. Data were analyzed by using Analysis of Varians $(p<0,05)$ and SPSS 16 for windows. Result: The result showed that administration of noni crude extract was significantly change the relative number of neutrophil (GR-1+). Conclusion: Treatment of noni (M. citrifolia) crude extract could increase relative amount of neutrophil (GR-1+) on infected S.aureus and without infected group. That might be caused by active compound on noni crude extract that can influence activity of increasing Granulocyte Colony Stimulating Factor (G-CSF) so can increase relative amount of neutrophil (GR-1+).
\end{abstract}

Keywords: S.aureus, M.citrifolia, neutrofil (GR-1+)

Tujuan: Penelitian ini bertujuan untuk mengetahui perubahan jumlah relatif sel neutrofil (GR-1+) pada mencit yang diinfeksi bakteri Staphylococcus aureus setelah pemberian ekstrak buah mengkudu (Morinda citrifolia L.). Metode: Mencit dibagi menjadi dua kelompok, kelompok non infeksi yaitu tanpa infeksi S.aureus dan kelompok infeksi dengan diinfeksi S.aureus. Masing-masing kelompok terdiri dari kontrol $(0$ $\mathrm{mg} / \mathrm{kg} \mathrm{BB})$, dosis 1 (25 mg/kg BB), dosis 2 (100 mg/kg BB), dosis 3 (300 mg/kg BB). Pemberian ekstrak buah mengkudu dilakukan selama 20 hari setiap pagi dan injeksi bakteri S.aureus dilakukan pada hari ke 21 dengan konsentrasi $109 \mathrm{sel} / \mathrm{mL}$. Jumlah relatif sel neutrofil (GR-1+) dihitung menggunakan software BD FACSCaliburTM Flowcytometer. Data hasil flowcytometry dianalisa menggunakan ANOVA $(p<0,05)$ menggunakan program SPSS 16 for windows. Hasil: Berdasarkan hasil penelitian ini diketahui bahwa pemberian ekstrak buah mengkudu dapat mempengaruhi jumlah relatif sel neutrofil (GR-1+). Kesimpulan: Pemberian ekstrak buah mengkudu dapat meningkatkan jumlah relatif sel neutrofil $(\mathrm{GR}-1+)$ pada kelompok non infeksi dan kelompok infeksi S.aureus. Hal ini dikarenakan adanya senyawa aktif pada buah mengkudu yang dapat mempengaruhi aktivitas peningkatan Granulocyte Colony Stimulating Factor (G-CSF) sehingga dapat meningkatkan populasi jumlah relatif sel neutrofil (GR-1+).

Kata kunci: S.aureus, M.citrifolia, neutrofil (GR-1+)

\section{PENDAHULUAN}

Salah satu penyebab tingginya angka kematian di beberapa Negara berkembang termasuk Indonesia yaitu peningkatan angka kejadian penyakit infeksi (Maranani,Z.Z.,2010). Hal ini termasuk angka kejadian penyakit infeksi yang disebbakan oleh flora normal pada manusia seperti bakteri Staphylococcus aureus (Franzeska, A.D, 2010).
S.aureus merupakan bakteri patogen gram positif yang bersifat invasif dan mampu menyebabkanberbagai penyakit pada hewan dan manusia. Pada hewan, S.aureus merupakan penyebab utama mastitis (radang ambing) pada sapi (Susanti R, Margareta R, 2003). Pada manusia, S.aureus dapat berperan sebagai agen pada berbagai penyakit termasuk infeksi kulit, ases, pneumonia, endokarditis, meningitis, dan sepsis (Jawetz,E, 
2005). Infeksi S.aureus menjadi masalah yang serius saat ini karena meningkatnya resistensi bakteri terhadap berbagai jenis antibiotik (Multi Drug Resistence/MDR). Antibiotik hanya membunuh atau menghambat bakteri yang sensitif. Hal ini menyebabkan seleksi strain yang resisten hingga akhirnya penggunaan antibiotik menjadi tidak efektif (Kumar, P., Sukhla I., Varshney S, 2011). Meluasnya resistensi bakteri terhadap obatobatan yang ada, mendorong pentingnya pencarian langkah alternatif dengan pemberian obat-obatan pencegah infeksi dari bahan alam (Mufidah,Z., 2014).

Berbagai jenis bahan alam telah dimanfaatkan oleh masyarakat Indnesia sebagai obat tradisional. Tanaman obat diketahui berpotensi dapat dikembangkan lebih lanjut sebagai upaya pencegahan atau pengobatan penyakit infeksi. Akan tetapi masih banyak yang belum dibuktikan aktivitasnya secara ilmiah. Masyarakat lebih memilih alternatif ini karena dianggap relatif lebih murah (dapat terjangkau oleh semua lapisan masyarakat), efisien, dan lebih aman dari efek samping dibandingkan dengan obat sintetik. Selain itu, tanaman obat memiliki potensi sebagai imunomodulator. Imunomodulator merupakan istilah yang diberikan pada suatu bahan yang dapat mempengaruhi sistem imun tubuh, sehingga mampu melawan serangan antigen.

Respon imun yang terjadi sebagai akibat adanya invasi dari bakteri S.aureus yaitu S.aureus sebagai antigen ketika masuk ke dalam tubuh akan dieliminasi oleh neutrofil (GR-1+) dan makrofag sebagai perannya pada sistem imun innate. Neutrofil merupakan pertahanan awal yang penting terhadap infeksi. Dalam keadaan normal, hanya sebagian kecil neutrofil yang ditemukan dalam sirkulasi ( $<2 \%$ dari 65 juta sel neutrofil pada tikus), dan sebagian besar neutrofil disimpan di sumsum tulang (UNUSA). Dalam responnya terhadap infeksi, neutrofil pada sumsum tulang akan dilepaskan dan mengontrol invading pathogen dalam perifer melalui fagositosis, agen oksidatif,

Tabel 1. Pengelompokan dosis ekstrak buah Mengkudu dan perlakuan infeksi bakteri S. aureus enzymatic digestion dan formaton of extracellular traps.

Neutrofil akan mati dalam proses bacterial killing (Raffaghello L, Bianchi G, etcl, 2008).

Berdasarkan uraian di atas, maka pelru dilakukan penelitian untuk mengetahui jumlah relatif sel neutrofil (GR-1+) pada mencit yang diinfeksi bakteri S. aureus setelah pemberian ekstrak buah mengkudu (Morinda citrifolia L.)

\section{METODE PENELITIAN}

Rancangan percobaan yang digunakan dalam penelitian ini adalah rancangan acak lengkap (RAL) pola faktorial dengan dua faktor, yaitu kelompok mencit yang tidak diinfeksi S. aureus(non infeksi) dan kelompok mencit yang diinfeksi S. aureus (infeksi). Penelitian ini menggunakan hewan coba mencit specific pathogen free strain Deutschland Denken Yonken (DDY) jenis kelamin betina, umur enam minggu dengan rerata berat badan 25 gram didapatkan dari Laboratorium Penelitian dan Pengujian Terpadu (LPPT) Universitas Gajah Mada Yogyakarta. Penggunaan hewan coba telah mendapatkan sertifikat Laik etik no.89 dari Komite Laik Etik Universitas Brawijaya. Herba yang diuji adalah buah mengkudu yang didapatkan dari daerah Joyotambaksari Malang, dan bakteri uji S. aureus didapatkan dari Laboratorium Mikrobiologi, Fakultas Kedokteran Universitas Brawijaya.

\section{PENGELOMPOKAN PERLAKUAN HEWAN COBA}

Hewan coba berupa mencit sebanyak 32 ekor dibagi menjadi delapan kelompok perlakuan, masing-masing kelompok terdiri dari empat ekor. Mencit diaklimasi selama satu minggu, kemudian dibagi menjadi dua kelompok perlakuan. Pada masing-masing kelompok menggunakan tiga variasi dosis sebagaimana disajikan pada Tabel 1

\begin{tabular}{|c|c|c|}
\hline Infeksi S. aureus & \multicolumn{2}{|c|}{ Perlakuan Ekstrak Buah Mengkudu } \\
\hline \multirow[t]{4}{*}{ Non Infeksi (F1) } & P0F1 (K-) & Kontrol Normal \\
\hline & P1F1 & $\begin{array}{l}\text { Ekstrak buah Mengkudu dosis } 1(25 \mathrm{mg} / \mathrm{kg} \mathrm{BB})- \\
\text { non infeksi } S \text {. aureus }\end{array}$ \\
\hline & P2F1 & $\begin{array}{l}\text { Ekstrak buah Mengkudu dosis } 2(100 \mathrm{mg} / \mathrm{kg} \mathrm{BB})- \\
\text { non infeksi } S \text {. aureus }\end{array}$ \\
\hline & P3F1 & $\begin{array}{l}\text { Ekstrak buah Mengkudu dosis } 3(300 \mathrm{mg} / \mathrm{kg} \mathrm{BB})- \\
\text { non infeksi } S \text {. aureus }\end{array}$ \\
\hline \multirow[t]{4}{*}{ Infeksi (F2) } & P0F2 $(\mathrm{K}+)$ & Kontrol Positif \\
\hline & P1F2 & Ekstrak buah Mengkudu dosis $1(25 \mathrm{mg} / \mathrm{kg} \mathrm{BB})-$ infeksi S. aureus \\
\hline & P2F2 & $\begin{array}{l}\text { Ekstrak buah Mengkudu dosis } 2(100 \mathrm{mg} / \mathrm{kg} \mathrm{BB})- \\
\text { infeksi S. aureus }\end{array}$ \\
\hline & P3F2 & Ekstrak buah Mengkudu dosis $3(300 \mathrm{mg} / \mathrm{kg} \mathrm{BB})-$ infeksi S. aureus \\
\hline
\end{tabular}


Bakteri S. aureuspada medium nutrient agar (NA) yang telah dikonfirmasi sebelumnya dibiakkan pada medium nutrient broth (NB) cair dan diinkubasi selama 1 x 24 jam. Selanjutnya diambil sebanyak satu $\mathrm{mL}$ dan ditambahkan sembilan $\mathrm{mL}$ medium $\mathrm{NB}$ baru. Kemudian dilakukan proses penghitungan bakteri dengan menggunakan haemacytometer setiap satu jam, sampai mendapatkan konsentrasi sel bakteri 109 $\mathrm{sel} / \mathrm{mL}$. Setelah mendapatkan konsentrasi sel bakteri $109 \mathrm{sel} / \mathrm{mL}$, kemudian dilakukan sentrifuse dengan kecepatan 10.000 rpm selama 10 menit pada suhu $25^{\circ} \mathrm{C}$. Pellet yang diperoleh selanjutnya disuspensi dengan satu mL PBS. Suspensi tersebut selanjutnya diinjeksikan pada hewan coba secara intraperitoneal dengan volume $100 \mu \mathrm{L}$. Injeksi dilakukan pada hari ke 21 setelah perlakuan pemberian ekstrak buah mengkudu.

\section{UJI KONFIRMASI KEBERADAAN BAKTERI S. AUREUS DI DALAM DARAH MENCIT}

Uji konfirmasi dilakukan untuk mengetahui keberadaan bakteri S. aureus di dalam darah mencit. Uji konfirmasi dilakukan pada hari ke 22 setelah pemberian ekstrak buah mengkudu selama 20 hari dan injeksi bakteri S. aureuspada hari ke 21. Darah diambil melalui ekor mencit sebanyak $\pm 50 \mu \mathrm{L}$ dan diletakkan di dalam tabung eppendorf, kemudian ditambah dengan $450 \mu \mathrm{L} \mathrm{NaCl}$ fisiologis $0,9 \%$. Selanjutnya, darah yang sudah dicampur dengan $\mathrm{NaCl}$ fisiologis kemudian diinokulasikan pada 4,5 $\mathrm{ml}$ media NB di dalam tabung reaksi. Kemudian dilakukan inkubasi pada shaker dengan suhu $37^{\circ} \mathrm{C}$, $120 \mathrm{rpm}$ selama 36 jam. Setelah dilakukan inkubasi, maka dilakukan penanaman pada media mannitol salt agar(MSA). Diambil sebanyak $\pm 2 \mathrm{~mL}$ cairan hasil inkubasi dan dilakukan penanaman pada media MSA dengan carapour plate. Kemudian dilakukan inkubasi pada suhu $37^{\circ} \mathrm{C}$ selama 24 jam. Bakteri S. aureus mengubah warna media dari merah menjadi kuning.

\section{ISOLASI SEL NEUTROFIL DARI SUMSUM TULANG MENCIT}

Isolasi sel dilakukan pada hari ke 25 , yaitu empat hari setelah perlakuan infeksi bakteri S. aureus. Sel diisolasi dari sumsum tulang femur dan tibia mencit. Tulang femur dan tibia mencit yang telah dibersihkan dari sisa jaringan otot yang menempel kemudian diflush dengan Phosphate Buffer Saline (PBS) menggunakan jarum $1 \mathrm{~mL}$, kemudian dihomogenkan dengan cara pipetting. Selanjutnya sel-sel yang diperoleh disaring menggunakan wire. Kemudian hasil yang diperoleh disentrifugasi dengan kecepatan $2500 \mathrm{rpm}$ pada suhu $4^{\circ} \mathrm{C}$ selama 5 menit. Supernatan yang diperoleh dibuang dan pellet diresuspensi dengan PBS $1 \mathrm{~mL}$. Selanjutnya dilakukan pipeting untuk mendapatkan homogenat. Sebanyak $200 \mu \mathrm{L}$ homogenat dipindahkan pada tabung mikrosentrifuse baru dan ditambah $500 \mu \mathrm{L}$ PBS. Kemudian dilakukan sentrifuse pada $2500 \mathrm{rpm}$, suhu $4^{\circ} \mathrm{C}$ selama 5 menit. Supernatan dibuang dan pellet selanjutnya diinkubasi dengan antibodi untuk proses analisis selanjutnya.

\section{ANALISIS FLOWCYTOMETRY}

Analisis Flowcytometry dilakukan untuk mendeteksi populasi sel yang mengekspresikan GR1+. Sel-sel yang diisolasi dari sumsum tulang diinkubasi dengan antibodi yang sesuai selama 15 menit dalam ice box. Antibodi yang digunakan yaitu rat anti-mouse anti-GR-1 FITC conjugated. Sampel yang telah diinkubasi dengan antibodi ditambah $300 \mu \mathrm{L}$ PBS dan ditempatkan pada kuvet flowcytometer. Selanjutnya dilakukan koneksi dengan komputer dan flowcytometer disetting pada keadaan acquiring serta dilakukan setting sesuai parameter yang akan dianalisis. Selanjutnya dipilih acquire dan flowcytometerakan menghitung jumlah sel total serta jumlah sel yang terdeteksi oleh label antibodi. Hasil yang diperoleh selanjutnya diolah dengan BD cellquest Pro TM.

\section{ANALISIS DATA}

Data hasil dari mesin Flowcytometry dianalisis menggunakan softwareCellQuest. Data dari mesin Flowcytometry dimasukkan dalam program CellQuest. Selanjutnya program diatur sesuai pewarnaan dan jenis sel yang diidentifikasi. Gated dilakukan berdasarkan pola ekspresi sel yang terlihat dalam layar komputer. Data hasil analisis menggunakan CellQuest selanjutnya ditabulasi, kemudian diuji statistik menggunakan two way ANOVA (Analysis Of Variance) melalui program SPSS 16.0. Apabila diperoleh hasil yang signifikan $(\mathrm{p}<0,05)$, maka dilakukan uji lanjut menggunakan Tukey.

\section{HASIL DAN PEMBAHASAN}

Neutrofil merupakan sel yang mempunyai peran penting dalam sistem imunitas innate. Mature neutrofil dibedakan melalui karakteristik segmen nuclear morphology, dan terdiri dari organel yang bertanggung jawab pada fagositosis, bacterial clearance dan respon inflamasi. Neutrofil berdiferensiasi di sumsum tulang dan dapat diklasifikasikan menjadi subset mature berdasarkan karakteristik morfologi(promyelocytes, myelocytes, 
metamyelocytes, dan band-segmented neutrophils) (Zhang P, Quinton LJ, etcl, 2005). Sel neutrofil dapat dideteksi melalui metode flowcytometri dengan anti-Grl yang akan berikatan dengan molekul Ly-6G yang merupakan protein permukaan sel dengan berat molekul 21-25 kDa yang dikenal sebagai myeloid differentiation antigen Gr-1. Protein ini diekspresikan oleh lineage myeloid pada beberapa fase perkembangannya di sumsum tulang (Dumortier, A., Peggy K, etcl, 2005).

Hasil analisa flowcytometri (Gambar 1) yang kemudian diuji menggunakan ANOVA, didapatkan data bahwasannya perlakuan pemberian ekstrak buah M. citrifolia L. (dosis $25 \mathrm{mg} / \mathrm{kg} \mathrm{BB}, 100$ $\mathrm{mg} / \mathrm{kg} \mathrm{BB}$, dan $300 \mathrm{mg} / \mathrm{kg} \mathrm{BB}$ ) pada mencit yang kemudian diinfeksi S.aureus memberi pengaruh nyata $(\mathrm{p}<0.05)$ terhadap populasi jumlah relative sel GR-1+ pada sumsum tulang mencit. Untuk mengetahui perlakuan yang paling berpengaruh terhadap jumlah relatif GR-1+ maka dilakukan uji lanjut menggunakan uji BNJ 0.05. Berdasarkan hasil BNJ 0.05 dari rerata jumlah GR-1+ didapatkan notasi BNJ yang disajikan pada Gambar 2.
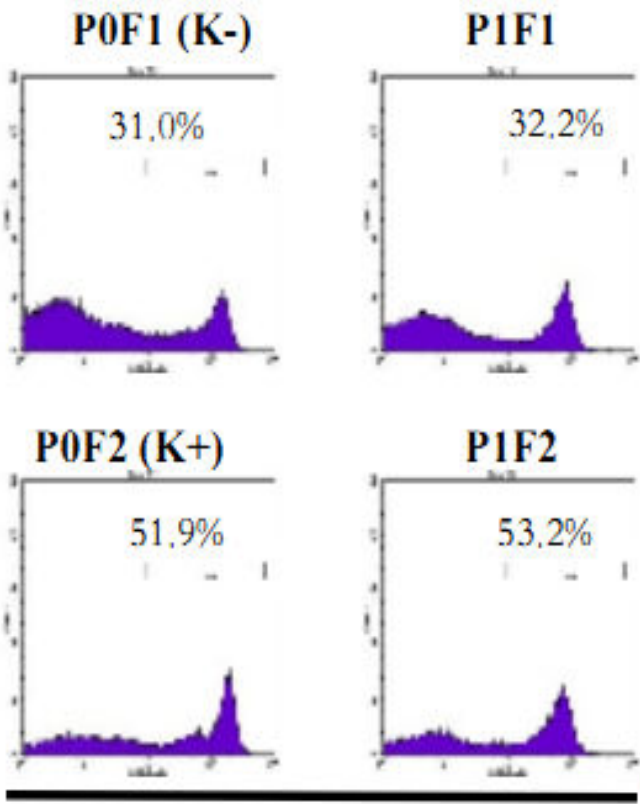

PIF1

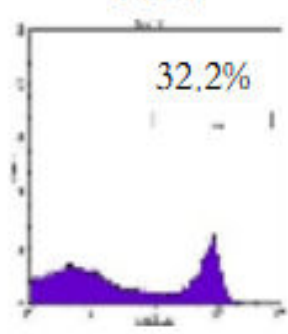

P1F2

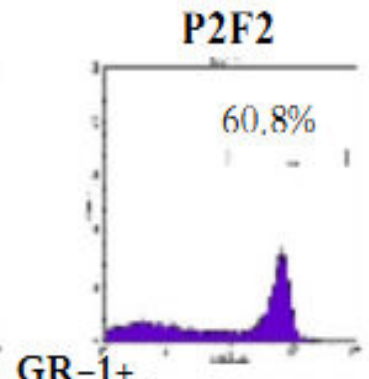

P2F1

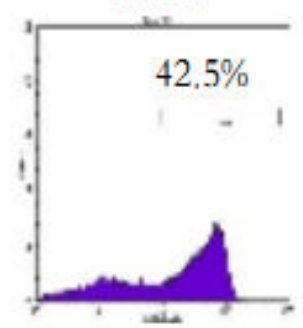

P2F2

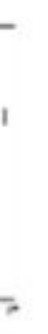

P3F1

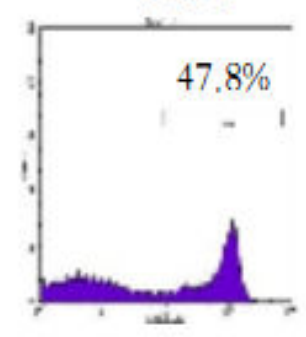

P3F2

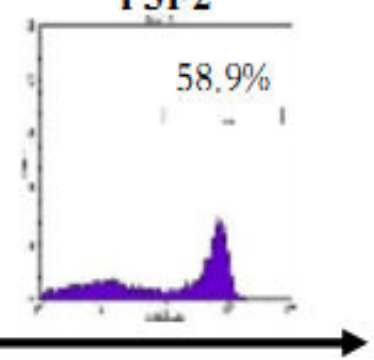

Gambar 1. Persentase jumlah relatif sel neutrofil (GR-1+) pada setiap perlakuan hasil analisa menggunakan flowcytometri pada organ sumsum tulang $(\mathrm{K}-=$ kontrol negative, $\mathrm{K}+=$ kontrol positif, $\mathrm{F} 1=$ Faktor non infeksi, F2 = Faktor non infeksi, $\mathrm{P} 0=$ dosis $0, \mathrm{P} 1=$ dosis $25 \mathrm{mg} / \mathrm{kg} \mathrm{BB}, \mathrm{P} 2=$ dosis $100 \mathrm{mg} / \mathrm{kg} \mathrm{BB}, \mathrm{P} 3=$ dosis $300 \mathrm{mg} / \mathrm{kg} \mathrm{BB})$. 


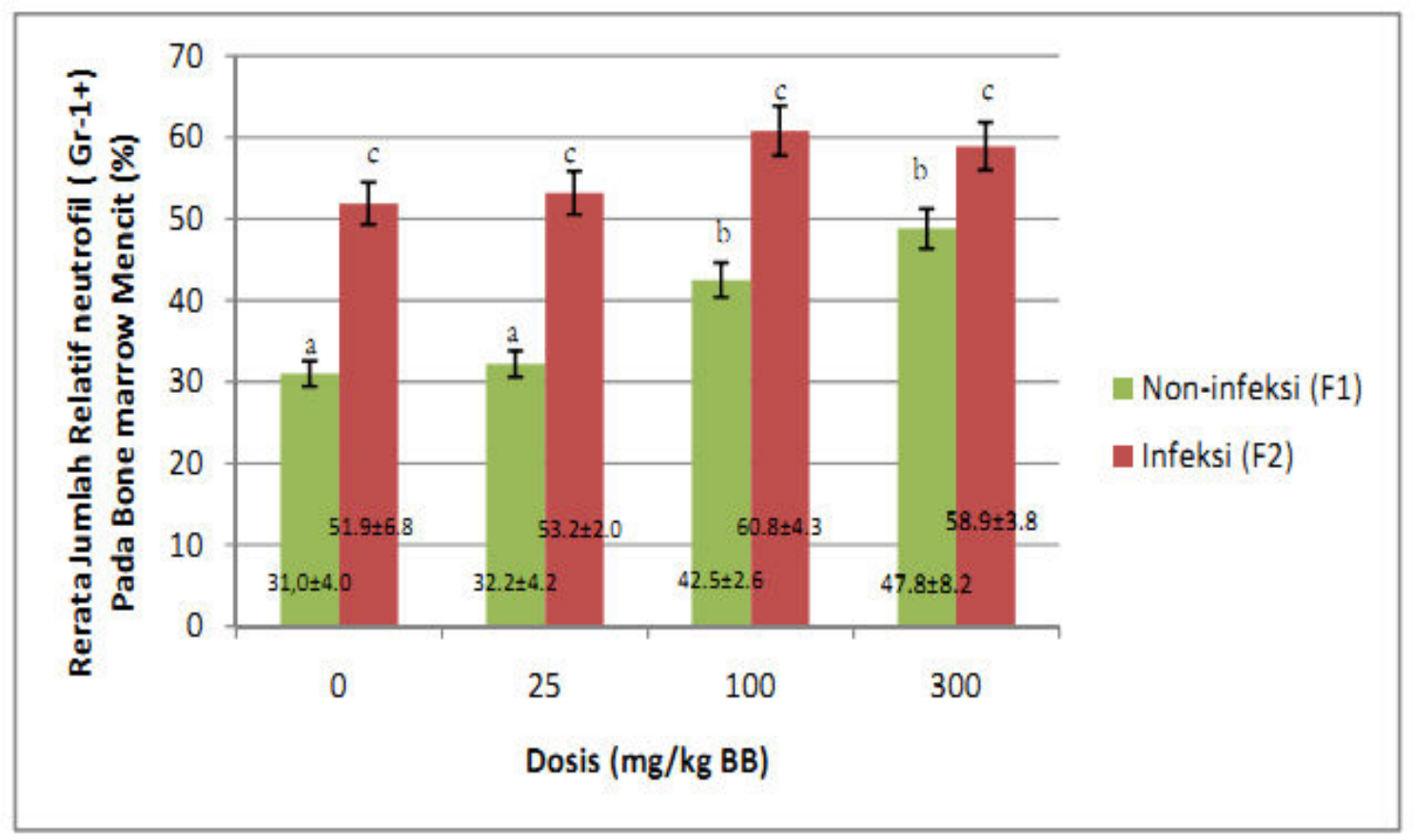

Gambar 2. Rerata persentase jumlah relative sel neutrofil (GR-1+) dan hasil uji BNJ pada setiap perlakuan hasil analisa menggunakan flowcytometri pada organ sumsum tulang (F1 = Faktor Non Infeksi, F2 = Faktor Infeksi).

Berdasarkan data hasil analisis flowcytometri yang kemudian dilanjutkan dengan uji ANOVA, diketahui bahwa pemberian ekstrak buah $M$. citrifolia L. dapat meningkatkan jumlah relatif populasi GR-1+ pada sumsum tulang mencit. Pada kelompok non infeksi (F1), didapatkan data bahwasannya pada mencit kelompok kontrol normal (0 $\mathrm{mg} / \mathrm{kg}$ BB) memiliki jumla relatif GR-1+ sebanyak $31.0 \%$ dan ketika diberi perlakuan pemebrian ekstrak buah M.citrifolia L. secara oral terjadi peningkatan jumlah relative GR-1+ sebesar $1.2 \%$ namun tidak berbeda nyata $(\mathrm{p}>0.05)$ menjadi $32.2 \%$ pada perlakuan dosis $25 \mathrm{mg} / \mathrm{kg}$ BB. Pemberian ekstrak buah M.citrifolia L. dosis dua dan tiga dapat meningkatkan jumlah relatif GR-1+ dan berbeda nyata dengan kontrol negatif $(0 \mathrm{mg} / \mathrm{kg}$ BB) yaitu menjadi $42.5 \%$ pada pemberian M.citrifolia L. dosis $300 \mathrm{mg} / \mathrm{kg}$ BB. Hasil penelitian Bresson dkk (2008), menyebutkan bahwa pemberian ekstrak daun M.citrifolia L. dosis 250 $\mathrm{mg} / \mathrm{kg}$ BB dapat meningkatkan jumlah absolut sel neutrofil pada adarah tikus betina.

Pada kelompok infeksi (F2), yaitu kelompok perlakuan yang diberi ekstrak buah M.citrifolia L. dosis $25 \mathrm{mg} / \mathrm{kg}$ BB dan $300 \mathrm{mg} / \mathrm{kg}$ BB selama 20 hari dan kemudian diinfeksi bakteri S.aureus pada hari ke-21 memiliki peningkatan jumlah relatif GR$1+$ akan tetapi tidak berbeda nyata jika dibandingkan dengan perlakuan kontrol posistif, yaitu kelompok perlakuan yang diinfeksi dengan
S.aureus (F2) tanpa pemberian ekstrak buah M. citrifolia L. (0 mg/kg BB). Pada kelompok kontrol positif didapatkan data jumlah relatif GR-1+ sebanyak 51,9\%, kemudian pemberian ekstrak buah M.citrifolia L. diketahui dapat meningkatkan jumlah relatif GR-1+ yaitu menjadi $53.2 \%$ pada dosis $25 \mathrm{mg} / \mathrm{kg} \mathrm{BB}$, dan $60.8 \%$ pada dosis 100 $\mathrm{mg} / \mathrm{kg}$ BB dan $58.9 \%$ pada dosis $300 \mathrm{mg} / \mathrm{kg}$ BB.

Peningkatan populasi jumlah relative GR-1+ pada kelompok infeksi (F2) setelah pemberian ekstrak buah M. citrifolia L. diduga disebabkan karena adanya beberapa senyawa aktif pada buah $\mathrm{M}$. citrifolia L. yang dapat menstimulasi terbentuknya sel neutrofil (GR-1+) di sumsum tulang. Neutrofil akan merespon bakteri yang masuk ke dalam tubuh. Sebagai respon terhadap infeksi mikroba pathogen, neutrofil pada sumsum tulang akan dilepaskan dan mengontrol invading pathogen dalam perifer melalui fagositosis, oxidative agents, enzymatic digestion, dan pembentukan extracellular traps (Daley J.M., Thomay A.A., etcl, 2008). Neutrofil akan mati dalam proses killing bakteri dankemdian Granulocyte Colony Stimulating Factor (G-CSF) akan up-regulated untuk menginduksi granulopoiesis. GCSF merupakan sitokin hematopoietic atau hematopietic growth factor yang dapat menstimulasi proliferasi precursor granulosit, meningkatkan diferensiasi dan menstimulasi pelepasan neutrofil dari sumsum tulang (Navarini, A.A.,Karl S.L.,etcl, 2008). Adanya mediator 
tersebut menyebabkan stimulasi precursor hematopoietic yang berakibat peningkatan kecepatan proliferasi dan penglepasan neutrofil dari sumsum tulang ke sirkulasi (Gregory, 2007).

Neutrofil berasal dari sel induk yang sama dengan monosit. Neutrofil muda mempunyai inti lebih besar yang tidak terbagi dalm lobus-lobus. Sel ini dikenal dengan namastab cell atau neutrofil batang. Sementara itu pada sel yang matang, kromatin inti memadat dan membentuk lobus-lobus yang dihubungkan satu sama lain dengan benangbenang halus. Sel ini dikenal dengan nama leukosit PMN atau neutrofil segmen, yang ditandai dengan inti multilobus dan tumpukan granula pada sitoplasmanya (Komala, P.S.R., 2011). Neutrofil yang matang dapat dibedakan oleh karakteristik tersegmentasi morfologi nucleus, dan mengandung organel khusus yang bertanggung jawab untuk fagositosis, pembersihan bakteri dan respon inflamasi. Diferensiasi neutrofil dapat terjadi pada sumsum tuang dan dapat diklasifikasikan menjadi subset dari bentuk morfologi-promyelocytes, myelocytes, metamyelocytes dan band neutrofil tersegmentasi. Subset tersebut juga dapat menjadi sub typed terhadap ekspresi neutrofil tersegmentasi. Subset tersebut juga menjadi sub typed terhadap ekspresi neutrofil pada marker permukaan Mac-1 (CD11b) dan Gr-1: sel Mac-1+Gr-1lo kebanyakan terdiri dari myelocytes dan metamyelocytes, sementara sel Mac-1+Gr-1hi terdiri terutama band neutrofil matang yang tersegmentasi (Sunarno, 2007).

Pada penelitian ini, buah M.citrifolia L. diekstrak menggunakan pelarut air, sehingga ekstrak yang didapatkan masih berupa crude ekstrak yang dimungkinkan masih mengandung beberapa bahan aktif di dalam crude ekstrak anatar lain polifenol dan glikosida. Beberapa senyawa aktif yang didapatkan dari ekstrak buah M. citrifolia L. jika menggunakan pelarut air diantaranya yaitu senyawa glikosida dan fenol (Dumortier, A., Peggy $\mathrm{K}$, etcl, 2003). Populasi jumlah relatif GR-1+ mengalami peningkatan setelah pemberian ekstrak buah M. citrifolia L. seperti terlihat pada Gambar 2. Menurut hasil penelitian Alberta (2006), bahwa senyawa fenol dapat meningkatkan ativitas dari beberapa sitokin, diantaranya yaitu IL-3, Granulocyte Colony Stimulating Factor (G-CSF) dan Macrophage Colony Stimulating Factor (MCSF) (Murdiati, T.B., G. Adiwinata, D.Hildasari. 2000). Efek biologis IL-3 adalah membantu pertubuhan sel pluripoten dalam sumsum tulang, growth factor untuk monosit, sedangakan G-CSF dapat meningkatkan koloni neutrofil, eosinofil, dan makrofag dalam sumsum tulang, mengaktifkan granulosit matang. G-CSF dalam hal ini memiliki efek meningkatkan neutrofil dan M-CSF meningkatkan koloni makrofag (Alberta., 2006).
Dengan demikian, peningkatan populasi GR-1+ pada sumsum tulang diduga sebagai akibat adanya senyawa aktif pada ekstrak buah M. citrifolia L. yang mempengaruhi aktivitas peningkatan sitokin Granulocyte Colony Stimulating Factor (G-CSF) sehingga dapat meningkatkan populasi jumlah relative neutrofil (GR-1+). Ekstrak buah mengkudu (M. citrifolia) diketahui dapat mempengaruhi jumah relatif CD4+, CD8+, dan IFN- $\gamma$ (Mufidah, Z. 2014, Bratawidjaja K.G, Rengganis I., 2010). Senyawa aktif dari buah $M$. citrifolia L. meliputi polisakarida, alkaloid, dan anthraquinone dapat meningkatkan aktivitas fagositosis neutrofil secara invitro (Mufidah, Z., M.Rifa'i., S.Rahayu., 2013). Saat adanya infeksi, neutrofil akan mengeluarkan chemoattractans seperti cathepsins dan defensins yang menstimulasi akumulasi sel $\mathrm{T}$ pada titik terjadinya inflamasi. Neutrofil juga akan mentrigger aktivasi dari sel T untuk melepaskan sitokinsitokin (Nayak, S. 2009, Akira S. 2005).

\section{KESIMPULAN}

Buah mengkudu (M. citrifolia L.) mempunyai beberapa senyawa aktif yang mampu mempengaruhi jumlah relatif sel neutrofil. Buah mengkudu (M. citrifolia L.) dapat digunakan sebagai terapi pencegahan penyakit infeksi yang disebabkan bakteri S.aureus karena mempunyai senyawa aktif yang bersifat sebagai imunomodulator.

\section{SARAN}

Perlu dilakukan penelitian lebih lanjut untuk mengkaji pengaruh ekstrak buah mengkudu ( $\mathrm{M}$. citrifolia L.) terhadap beberapa sitokin (GCSF dan IL-3) sehingga bisa melengkapi data hasil penelitian tentang peran ekstrak buah mengkudu (M. citrifolia L.) terhadap peningkatan jumlah relatif sel neutrofil berkaitan dengan potensi buah mengkudu ( $\mathrm{M}$. citrifolia L.) sebagai imunomodulator.

\section{DAFTAR PUSTAKA}

Maranani, Z.Z. 2010. Influence Of Health Care Toward Staphylococcus aureus Infection and Antimicrobial Resistance In Patient Of dr. Kariadi Hospital Semarang Period 200892009. Thesis. Semarang: Universitas Diponegoro.

Franzeska, A.D. 2010. Influence Of Demographic Factor Toward Staphylococcus aureus Infection and Antimocrobial Resistance Patiens Of dr. Kariadi Hospital Semarang 2008-2009. Thesis. Semarang: Universitas Diponegoro.

Susanti R \& Margareta R. 2003. Aktivitas Fagositosis Neutrofil Terhadap Staphylococcus aureus Isolat Sapi di Jawa Tengah dengan Teknik Acridine Orange 
Fluorescence. Berk. Penel. Hayati: Hal.6166

Jawetz, E. 2005. Mikrobiologi Kedokteran. Jakarta: EGC.

Kumar, P., Sukhla I., Varshney S. 2011. Nasal screening of Healthcare workers for nasal carriage of coagulase positive MRSA and Prevalence of nasal Colonization with Staphylococcus aureus. Biology and Medicine. 3 (2): 182-186.

Mufidah, Z. 2014. Buah Mengkudu (Morinda citrifolia) Meningkatkan Respon Imunitas Mencit (Mus musculus) Terhadap Infeksi.

UNUSA, Bakteri Staphylococcus aureus. Jurnal Ilmu Kesehatan.

Raffaghello L, Bianchi G, Bertolotto M, Montecucco F, Busca A. 2008. Human messenchymal stem cells inhibit neutrophil apoptosis: A model for neutrophil preservation in the bone marrow niche. Stem Cells. 26:151-162

Zhang P, Quinton LJ, Gamble L, Bagby GJ, Summer WR. 2005. The granulopoistic cytokine response and enhancement of granulopoiesis in mice during endotoxemia. Shock 23: 344-352.

Dumortier, A., Peggy K, Philippe K., Susan C. 2003. Ikaros regulates neutrophil differentiation. Blood. 101 (6): 2219-2225.

Daley J.M., Thomay A.A., Connolly M.D., Reichner J.S., Albina J.E. 2008. Use Of Ly6g-Specific Monoclonal Antibody to Deplete Neutrophils In Mice. J Leukoc. Biol. 83: 64-70

Navarini, A.A., Karl S.L., Admar V., Mike R., Annelies S.Z., Victor N., Berhard O., Hans $\mathrm{H}$ dan Rolf M.Z. 2008. Innate Immuneinduced depletion of bone marrow neutrophils aggravates systemic bacterial infections. Proc Natl Acad Sci USA 10: 16

Gregory. 2007. Regulation of Systemic and local neutrophil responses by G-CSF during pulmonary Pseudomonas aeruginosa infection. Blood. 109 (8): 3235-43

Komala, P.S.R. 2011. The Effects of Fluvastatin on Delta of Leukocyte, neutrophil counts and serum concentration of alkaline phosphatase in wistar rats before and after exposure to cigarate smoke. Tesis. Program Magister Ilmu Biomedik Universitas Diponegoro.

Sunarno. 2007. The Effect of Phyllanthus niruri L in Neutrophil Percentages, Spleenic Bacterial Colonies and Liver Histopathology of Balb/C Mice Infected by Salmonella thypimurium. Tesis. Semarang: Universitas Diponegoro.

Dumortier, A., Peggy K, Philippe K., Susan C. 2003. Ikaros regulates neutrophil differentiation. Blood. 101 (6): 2219-2225.

Murdiati, T.B., G. Adiwinata dan D.Hildasari. 2000. To trace the active compound in mengkudu (Morinda citrifolia) with anthelmintic activity against Haemonchus contortus. Jurnal Ilmu Ternak dan Veteriner. 5 (4): 255-259

Alberta. 2006. Pengaruh The Hijau Terhadap Jumlah Eritrosit Mencit Balb/c yang Diberi Metotreksat. Karya Tulis Ilmiah. Semarang: Fakultas Kedokteran Universitas Diponegoro.

Bratawidjaja K.G \& Rengganis I. 2010. Imunologi Dasar. Jakarta: Balai Penerbit FKUI.

Mufidah, Z., M.Rifa'i., S.Rahayu. 2013. Immunomodulators activity of Noni (Morinda citrifolia) fruit extract in mice infected with Staphylococcus aureus. Jurnal Veteriner. 11 (4): 501-510

Nayak, S dan Sushma M. 2009. Immunostimulant activity of the extracts and bioactives of the fruits of Morinda citrifolia. Pharmaceutical Biology. 47 (3): 248-254.

Bhattacharjee R \& Akira S. 2005. Toll-like receptor signaling: Emerging opportunities in human diseases and medicine. Curr Immunol Rev 1: 81-90.

Pedraza S.S., Gonzales H.Y, Escobar G.A, dan Ramachandra L. $2006 . \quad$ The immunostimulant RU41740 from Klebsiella pneumonia actvates human cells in whole blood to potentially stimulate innate and adaptive immune response. Int Immunopharmacol 6: 635-646. 